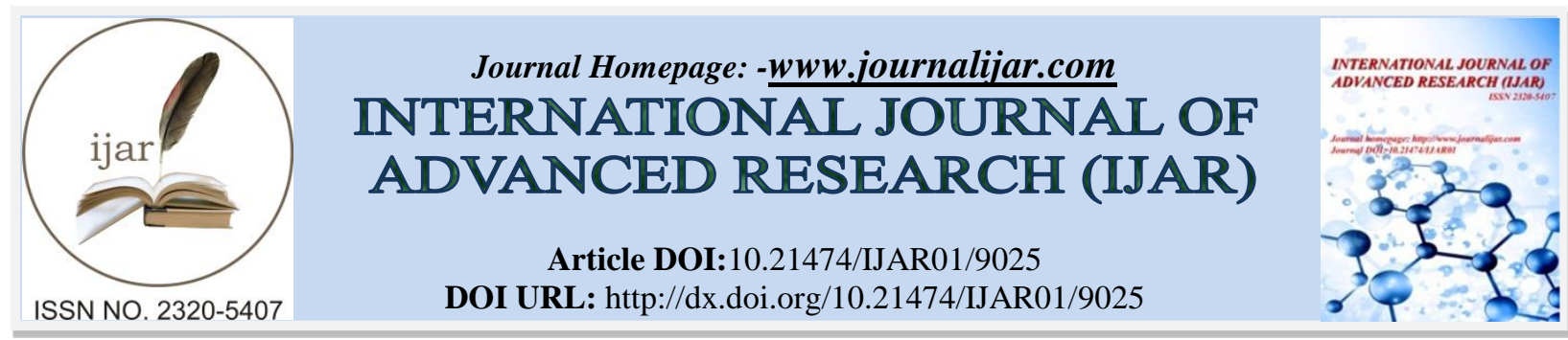

RESEARCH ARTICLE

\title{
IN VITRO ANALYSIS OF VIRULENCE FACTORS WHICH ENHANCES PATHOGENIC POTENTIAL WITH AN EMPHASIS ON BIOFILM FORMATION IN BACTEROIDES FRAGILIS GROUP.
}

Zomuanpuii Colney ${ }^{1}$ And Beena Antony ${ }^{2}$.
1. Research Scholar, Department of Microbiology, Father Muller Medical College\& Hospital, Mangalore, South Karnataka, 575002, India.

2. Professor, Department of Microbiology, Father Muller Medical College \& Hospital, Mangalore, South Karnataka, 575002, India.

\section{Manuscript Info}

n.......................

Manuscript History

Received: 04 March 2019

Final Accepted: 06 April 2019

Published: May 2019

Key words:-

$B$ fragilis group, beta-lactamse, biofilm, capsule, neuraminidase, virulence factors.

\section{Abstract}

Bacteroides fragilis group is the most frequently isolated pathogenic anaerobes with potent virulence determinants such as the ability to produce biofilm and presence of polysaccharides capsules which are responsible for the abscess formation. Enzymes such as beta- lactamase and neuraminidase are also implicated as virulence factors. The main aim of this study was to evaluate the virulence factors possessed by $B$ fragilis group isolated from clinical samples. The study was conducted in a tertiary care hospital in South Karnataka, India. A total of 72 strains isolated from various clinical samples were included in the study and tested for virulence factors and biofilm formation. Strains displaying encapsulation, beta-lactamase and neuraminidase enzymes were $75 \%, 77.7 \%, 69.4 \%$ respectively. Out of the 72 strains $73.6 \%$ were strong biofilm producers. In conclusion: The members of $B$ fragilis group possess many virulence factors which may contribute towards its pathogenicity.

Copy Right, IJAR, 2019,. All rights reserved.

\section{Introduction:-}

Bacteroides fragilis group, a non-sporing, non-motile, gram negative bacilli and an obligate anaerobe is the most frequently encountered organism with high pathogenic potential. (Soki et al., 2016) Due to its ability to produce diverse infections and frequent distribution as normal flora in various mucocutaneous sites, they are accounting 60$80 \%$ of the anaerobic infection. (Antony, 2016; Barlett, 2017)

They are known to produce many virulence factors. In the recent past, increased incidence of antimicrobial resistance was reported around the globe. The polysaccharide capsule is a virulence determinant which acts as defense against phagocytosis and responsible for the abscess formation. (Nakano and Avila Campos, 2004; Reis et al., 2014) Untreated abscess can cause obstructions and later disseminate resulting in bacteremia. (Wexler, 2007) It has been widely accepted that anaerobes produce enzymes such as beta lactamase that could inactivate penicillins, cephalosporinases that inactivates cephalosporins.(Livemore and Brown, 2001) Other enzymes such as neuraminidase, protease, hyaluronidase, chondratinsulfatase, gelatinase, collagenase, fibrinolysin, lecithinase, lipase secreted by some anaerobes have significant involvement in the process of infection and contributes to its pathogenic potential. (Wexler 2007; Duerden, 1994; Nagmoti, 2014; Moncla et al.,1990) 
Biofilm represents multicellular sessile growth which can colonize and adhere to surface of mucous membrane and other inert medical devices such as urine catheter and central line catheter which initiates infections. (De A et al., 2017, Bunyan et al., 2017) Demonstration for biofilm production has been seen in many bacteria and it has become the universal feature of bacteria. (Lemon et al., 2003)

The present study investigates the virulence factors and biofilm formation of $B$ fragilis group isolated from various clinical samples.

\section{Materials \& Method:-}

The present cross-sectional study was conducted for a duration of two years starting from January 2017 to December 2018 in a tertiary care hospital in Mangalore, coastal Karnataka, South India. Various clinical samples suggestive of $B$ fragilis group infections such as intra-abdominal infection, deep seated abscesses, female genitourinal tract were collected from patients of all age groups. The samples were inoculated in Robertson Cooked Meat Medium (RCM) and transported to microbiology laboratory for further investigation. The study was approved by Institutional Ethics Committee (FMMC/FMIEC/4229/2017). Demographic details of patients were taken from the medical records.

\section{Characterisation of $B$ fragilis group}

All the samples transported in RCM were incubated at temperature of $37^{\circ} \mathrm{C}$ for 24 hours. After incubation the samples were sub cultured from RCM onto anaerobic media such as Neomycin Blood agar (NBA) and selective agar for $B$ fragilis group, Bacteroides Bile Esculin Agar (BBE) (HiMedia Laboratories Pvt. Limited, India). Metronidazole disc $5 \mu \mathrm{g}$ was included on each plate for presumptive identification. The sub cultured plates were incubated in a transparent, BD Gaspak anaerobic jar using commercially available BD GasPak ${ }^{\mathrm{TM}}$ Gas Generating Sachet (Beckton-Dickinson and Co, USA) to create anaerobic environment at a temperature of $37^{\circ} \mathrm{C}$ for $48-72$ hours. Characterization of the isolates was performed by standard conventional biochemical test as per Wadsworth-KTL Manual for Anaerobic Bacteriology. ( Jousimies-Somer et al., 2002)

Small, circular, black colonies of $1 \mathrm{~mm}$ size on BBE showing pleomorphic gram-negative bacilli by gram stain will be presumptively identified as Bacteroides spp except $B$. vulgatus which does not hydrolyze esculin and do not form black colonies.

Special potency discs such as (Vancomycin $(5 \mu \mathrm{g})$, Kanamycin $(1000 \mu \mathrm{g})$ and Colistin $(10 \mu \mathrm{g})$ ) were used for grouping i.e. $B$ fragilis is resistant to all the 3 discs. Biochemical tests which includes growth in $20 \%$ bile, catalase test, indole test, esculin hydrolysis and sugar fermentation such as glucose, sucrose, lactose, maltose, rhamnose, trehalose, mannitol, arabinose, xylose, cellobiose for speciation.

\section{Demonstration of Virulence Factor}

\section{a. Capsule detection by Dry India Ink method:}

Encapsulated strains were detected by using dry India Ink method. (Cruickshank et al., 1965) Briefly a colony was emulsified in a drop of $6 \%$ dextrose solution mixed with India Ink on a clean slide. A thin film was made with the help of another slide. The slide was allowed to dry without blotting or heating and stained with $1 \%$ crystal violet for $1 \mathrm{~min}$. It was gently rinsed with water and allowed to air dry and observed under oil-immersion objective (100x) in the microscope. A distinct clear zone of at least half the width of bacterial cell surrounding the entire cell circumference of over $50 \%$ of the organism are considered as encapsulated strains.

\section{b. Beta-lactamase detection by Cefinase / Nitrocefin disk:}

Commercially available Nitrocefin disk (Sigma-Aldrich, St.Louis, USA) - 6mm diameter filter paper discs impregnated with chromogenic cephalosporin were used for the detection of beta-lactamase enzyme. The test was performed according to manufacturer's instructions. The disk was placed on a clean slide, moistened with one drop of deionized water. A few colonies were smeared onto the surface of the disk using sterile applicator stick. The development of red color on the smeared area indicates the presence of beta lactamase enzyme resulting in resistance to penicillin or cephalosporin activity. (Livermore and Brown., 2001)

\section{c. Detection of neuraminidase by filter paper spot test:}

The reagent 2'-(4-methulumbelliferyl)- $\alpha$-D-N-acetylneuraminic acid (Sigma-Aldrich Chemicals Pvt. India) was prepared in distilled water at a concentration of $110 \mu \mathrm{mol} / \mathrm{ml}$. It was stored frozen in $180 \mu$ volume until use. The stock solution was thawed and $20 \mu \mathrm{l}$ of a 1.0 -mol/liter sodium acetate buffer $(\mathrm{pH} 4.6)$ was added and poured in a 
petri dish. The filter paper (approximately 60 by $6 \mathrm{~mm}$ ) (No2; Whatman, Inc., Clifton) was moistened with the solution and spotted with one or two colonies, and incubated at $37^{\circ} \mathrm{C}$ for 15 mins. The filter paper was examined using Woodpecker light cure unit 2300mw/cm (385-515nm) (Healthtech Engineer Pvt Ltd, India). The enzyme activity will be observed as a fluorescent spot on the filter paper. (Moncla et al.,1990)

\section{d. Quantitative biofilm formation assay}

Quantitative biofilm formation assay procedure was followed as described by Donelli et al, 2012. Pure cultures maintained in Brucella Blood Agar (BrBA) were suspended in pre reduced Brain Heart Infusion (BHI) broth and incubated anaerobically for 72 hours. Turbidity of culture broth was adjusted to $0.5 \mathrm{McFarland}$ standard. $20 \mu \mathrm{l}$ of culture broth and $180 \mu \mathrm{l}$ fresh BHI broth containing $1 \%$ glucose were transferred each well of flat-bottomed plastic tissue culture plates (Himedia Laboratories, India) in triplicate. Fresh BHI with $1 \%$ glucose was used as negative control. The plates were covered with a lid and incubated anaerobically for $48 \mathrm{hrs}$ at $37^{\circ} \mathrm{C}$ and washed three times with $200 \mu \mathrm{l}$ Phosphate Buffer Solution (PBS). After drying for 1 hour at $60^{\circ} \mathrm{C}$, it was stained with $150 \mu 1$ of $2 \%$ Hucker's crystal violet for 5 min. The plate was rinsed off gently with water to drain the excess stain and left overnight for drying. The dye was solubilized with $150 \mu \mathrm{l}$ of $30 \%$ (v/v) glacial acetic acid. Using microplate reader model 680 (Biorad Laboratories, India) optical density of the wells were measured at 570nm. The results were interpreted according to the criteria given by Stephanovic et al,2000.

The cut-off OD (ODc) is defined as three standard deviations above the mean OD of the negative control. The stains were categorized by strength of adherence based on OD values.: nonadherent (OD $\leq$ ODc), weakly adherent (ODc $<$ $\mathrm{OD} \leq 2 \mathrm{xODc})$, moderately adherent $(2 \mathrm{xODc}<\mathrm{OD} \leq 4 \mathrm{xODc})$, and strongly adherent $(4 \mathrm{xODc}<\mathrm{OD})$ (Stephanovic et al.2000)

\section{Statistical analysis}

The results were analyzed by frequency distribution and chi-square using SPSS 22 version statistical software. In all cases $\mathrm{p}$ value $>0.05$ was considered significant.

\section{Results:-}

A total of 72 strains of $B$ fragilis group were isolated from [pus 25(34.7\%), high vaginal swab 26 (36.1\%), blood and body fluid $6(8.3 \%)$, wound swab 14(19.4\%)] were characterized using standard biochemical reactions. $B$ fragilis is the most common isolates in this study $37(51.4 \%)$.

Among the 72 strains tested for virulence factors, 54 (75\%) were encapsulated isolates and presence of betalactamase and neuraminidase were $56(77.7 \%)$ and $50(69.4 \%)$ respectively. The results are shown in table 1. In vitro quantitative biofilm investigation was done based on their ability of adherence and relative results are given in table 2 .

\section{Discussion:-}

$B$ fragilis group is an opportunistic obligate anaerobe that occurs as normal flora which cause endogenous infection. $B$ fragilis is reported as the most frequent isolate among the members of the group with maximum virulence potential. Virulence factors are components or molecules synthesized by the bacteria to contribute to its pathogenicity and cause infections. Among the virulence factors, the polysaccharide capsule occupies the outer most layer and acts as the first line of defense against phagocytosis. (Rendueles, 2017) Various investigators could successfully induce abscess formation in experimental animals using B fragilis capsule. (Conye et al., 2000, Tzianaboz et al., 2000)

In addition, Tzianaboz et al., 2000 could demonstrate development of antibodies preventing abscess formation by systematic capsular injections. A study reported a particular capsular polysaccharides (CPS5) was found in human samples which can produce multiple capsule types to survive antibiotic therapy. (Porter et al.,2017) In our study 54 (74\%) strains produced capsule.

As documented in literature, enzymes particularly beta-lactamase including penicillinases, cephalosporinases and the metallo-beta-lactamases were responsible for resistance to beta lactam agents (Tally, 1979). These enzymes were commonly found in all Bacteroides species (Livermore and Brown, 2001) Other mechanism such as changes in penicillin binding protein and outer membrane permeability to beta-lactams were also reported.(Wexler, 1991, 
Edward et al., 1997) Even though some investigators reported beta-lactamase production in a range of $96-99 \%$ (Aldridge et al.,2001. Fernandes-Canigia et al.,2012) and our results showed only $77.7 \%$. This might be due to the inclusion of comparatively smaller number of isolates.

Bacteroides species utilizes indigestible polysaccharides that are composed of complex sugars including $\mathrm{N}$-acetylD-glucosamine and $\mathrm{N}$-acetylneuraminic acids. The production of neuraminidase can cause infection. (Yamamoto et al., 2018). Moncla et al., 1990 reported that sialidase enzyme was detected in $94 \%$ of the strains whereas in this study only $69.4 \%$ produced neuraminidase. In the present study, stock cultures which was collected for a period of 1 year has been employed. Geographical distribution, whether or technical short comings are responsible for the decreasing incidence of positivity to be ruled out by studying larger number of cases.

Bacterial biofilm producers protect itself from host immune defenses and mildly responds to antimicrobial therapy. Studies report that biofilm provides refuge for cancerous bacteria. As reported by Dejea et al.,2018 B fragilis toxin (bft) causes to stimulate release of IL-17, leading to immune cell infiltration and colon inflammation in patient with familial adenomatous polyposis (FAP) (Dejea et al.,2018, Dickson, 2018) Another study reports 83.9\% of $B$ fragilis isolates from women with $\mathrm{BV}$, were strong biofilm producers and $16.1 \%$ were moderate biofilm producer. (Bunyan et al.,2017)

Table 1:-Detail of virulence factors detected in B fragilis (72 strains)

\begin{tabular}{|l|l|l|l|}
\hline & Virulence factors & Interpretation & Negative \\
\cline { 3 - 4 } & & Positive & $18(25 \%)$ \\
\hline 1. & Capsule & $54(75 \%)$ & $16(22.2 \%)$ \\
\hline 2 & Beta lactamase & $56(77.7 \%)$ & $22(30.5 \%)$ \\
\hline 3 & Neuraminidase & $50(69.4 \%)$ & \\
\hline
\end{tabular}

Table 2:-Analysis of Biofilm production by $B$ fragilis group (72 strains)

\begin{tabular}{|c|c|c|c|c|c|c|}
\hline & & \multicolumn{4}{|l|}{ Biofilm } & \\
\hline Species & $\begin{array}{ll}\text { No of } \\
\text { strains } \\
\text { tested }\end{array}$ & $\begin{array}{l}\text { Strong } \\
\text { producers }\end{array}$ & $\begin{array}{l}\text { Moderate } \\
\text { producers }\end{array}$ & $\begin{array}{l}\text { Weak } \\
\text { producers }\end{array}$ & $\begin{array}{l}\text { Non } \\
\text { producers }\end{array}$ & P value \\
\hline B fragilis & 37 & $\begin{array}{l}30 \\
(41.7 \%)\end{array}$ & $\begin{array}{l}7 \\
(9.5 \%)\end{array}$ & 0 & 0 & \multirow{6}{*}{0.018} \\
\hline B theitaiotamicron & 16 & $\begin{array}{l}11 \\
(15.3 \%)\end{array}$ & $\begin{array}{l}3 \\
(4.2 \%) \\
\end{array}$ & $\begin{array}{l}1 \\
(1.4 \%)\end{array}$ & $\begin{array}{l}1 \\
(1.4 \%)\end{array}$ & \\
\hline B ovatus & 12 & $\begin{array}{l}8 \\
(11.1 \%) \\
\end{array}$ & 0 & $\begin{array}{l}2 \\
(2.8 \%) \\
\end{array}$ & $\begin{array}{l}2 \\
(2.8 \%) \\
\end{array}$ & \\
\hline$B$ distansonis & 5 & $\begin{array}{l}3 \\
(4.1 \%)\end{array}$ & $\begin{array}{l}1 \\
(1.4 \%)\end{array}$ & - & $\begin{array}{l}1 \\
(1.4 \%)\end{array}$ & \\
\hline B vulgatus & 2 & $\begin{array}{l}1 \\
(1.4 \%)\end{array}$ & - & $\begin{array}{l}1 \\
(1.4 \%)\end{array}$ & - & \\
\hline Total & $\begin{array}{l}72 \\
100 \% \\
\end{array}$ & $\begin{array}{l}53 \\
73.6 \% \\
\end{array}$ & $\begin{array}{l}11 \\
15.3 \%\end{array}$ & $\begin{array}{l}4 \\
5.6 \% \\
\end{array}$ & $\begin{array}{l}4 \\
5.6 \%\end{array}$ & \\
\hline
\end{tabular}

\section{Conclusion:-}

On the bases of data obtained in this investigation, $B$ fragilis group tends to expresses many virulence factors and which enable them to be potent virulent pathogen.

\section{Conflicts of interest:}

The authors stated that no conflict of interest.

\section{Reference:-}

1. Aldridge KE, Ashcraft D, Cambre K, Pierson CL, Jenkins SG, Rosenblatt JE. (2001) Multicenter survey of the changing in vitro antimicrobial susceptibilities of clinical isolates of Bacteroides fragilis group, Prevotella, Fusobacterium, Porphyromonas, and Peptostreptococcus species. Antimicrob Agents Chemother. 45:1238-43. 
2. Antony B, Justin S, Raveendran R, Shetty AK, Kuruvilla TS, Boloor R. (2016) Spectrum of anaerobes encountered in surgical infections in a tertiary care hospital in Mangalore, coastal Karnataka: A prospective study. Muller J Med Sci Res 7:40-3

3. Barlett JG (2017) Anaerobic bacterial infection, [Internet]. Uptodate 2017. [cited 19 June 2017]. Available from https://www.uptodate.com/contents/anaerobic-bacterial-infections.

4. Bunyan IA, Umran BJ, Salman ZK. (2017)Biofilm formation by Bacteroides fragilis isolated from women with bacterial vaginosis. Wor J of Pharma Resear 6:219-23.

5. Conye M. J., W. Kalka-Moll, A. O. Tzianabos, D. L. Kasper, and L. E. Comstock. (2000) Bacteroides fragilis NCTC9343 produces at least three distinct capsular polysaccharides: cloning, characterization, and reassignment of polysaccharide $\mathrm{B}$ and $\mathrm{C}$ biosynthesis loci. Infect. Immun. 68:6176-81

6. Cruickshank R. Medical Microbiology: a guide to the laboratory diagnosis and control of infection. 1965, 1 lth ed., E. \& S. Livingstone Ltd, Edinburgh, pp 657-660.

7. De A, Raj HJ, Haldar J, Mukherjee P, Maiti PK.(2017) Biofilm colonization in chronic treatment refractory infections presenting with discharging sinuses: A study in a tertiary care hospital of Eastern India. J Lab Physicians 9:125-131.

8. Dejea C M, Fathi P, CraigJ M, Boleij A, Taddese R, Geis A L, Wu A, Shields C E D et al. (2018)Patients with familial adenomatous polyposis harbor colonic biofilms containing tumorigenic bacteria. Science 359:592-7.

9. Dickson I.(2018) Colorectal cancer: Bacterial biofilms and toxins prompt a perfect storm for colon cancer. Nat Rev Gastroenterol Hepato 115:129.

10. Donelli G, Vuotto C, Cardines R, Mastrantonio P. (2012)Biofilm-growing intestinal anaerobic bacteria. FEMS Immunol Med Microbiol.65:318-25.

11. Duerden BI. (1994)Virulence factors in anaerobes. Clin. Infect. Dis. 14:S253-259.

12. Edwards R. (1997)Resistance to beta-lactam antibiotics in Bacteroides spp. J Med Microbiol. 46: 979-86.

13. Fernández-Canigia L, Litterio M, Legaria MC, Castello L, Predari SC, Di Martino A, Rossetti A, Rollet R, Carloni G, Bianchini H, Cejas D, Radice M, Gutkind G; Anaerobe Surveillance Team.(2012) First national survey of antibiotic susceptibility of the Bacteroides fragilis group: emerging resistance to carbapenems in Argentina. Antimicrob Agents Chemother 5: 1309-14.

14. Jousimies-Somer H, Summanen P, Citron DM, Baron EJ, Wexler HM, Finegold SM Wadsworth-KTL Anaerobic Bacteriology Manual. 2002, 6th ed. Belmont: Star Publishing Company.

15. Lemon K P, Earl AM, Vlamakis HC, Aguilar C, Kolter R. (2003)Biofilm development with an emphasis on Bacillus subtilis. Curr Top Microbiol Immunol 3:221-16.

16. Livermore DM, Brownb D F J. (2001) Detection of $\beta$-lactamase-mediated resistance. J Antimicrob Chemother. 4859-64.

17. Moncla BJ, Braham P, Hillier SL. (1990) Sialidase (neuraminidase) activity among gram-negative anaerobic and capnophilic bacteria. J Clin Microbiol. 28:422-5.

18. Nakano V, Avila-Campos MJ(2004) Virulence markers and antimicrobial susceptibility of bacteria of the Bacteroides fragilis group isolated from stool of children with diarrhea in São Paulo, Brazil.Mem Inst Oswaldo Cruz 99:307-12.

19. Nagmoti J M.(2014) Virulence Factors of Nonsporing Anaerobes; A revisit to explore their diagnostic \& therapeutic potential. J Pub Health Med Res 2:1-7.

20. Patterson JL, Stull-Lane A, Girerd PH, Jefferson KK.(2010) Analysis of adherence, biofilm formation and cytotoxicity suggests a greater virulence potential of Gardnerella vaginalis relative to other bacterial-vaginosisassociated anaerobes. Microbiology156:392-9.

21. Porter NT, Canales P, Peterson DA, Marten EC. (2017) A subset of polysaccharide Capsule I Human Symbiont Bacteroides theitaiotamicron promote increased competitive fitness in mouse gut.Cell Host \& Microbe 22:494506.

22. Reis A C M, Silva J O, LaranjeiraI B J; PinheiroII A Q, Carvalho C BM(2014)Virulence factors and biofilm production by isolates of Bacteroides fragilis recovered from dog intestinal tracts. Braz J Microbiol. 45: 647-50.

23. Rendueles O.(2017) Abundance and co-occurrence of extracellular capsules increase environmental breadth: Implications for the emergence of pathogens. PLoS Pathog 13:7.

24. Sóki J, Hedberg M, Patrick S, Bálint B, Herczeg R, Nagy I, Hecht DW, Nagy E, Urbán E(2016). Emergence and evolution of an international cluster of MDR Bacteroides fragilis isolates. J Antimicrob Chemother. 72:4418.

25. Stepanovic S, Vukovic D, Dakic I, Savic B and Svabic-Vlahovic M. (2000) A modified microtiter-plate test for quantification of Staphylococcal biofilm formation. J Microbiol Methods 40:175-179. 
26. Tally FP, O'Keefe JP, Sullivan NM, and Gorbach SL. (1979) Inactivation of Cephalosporins by Bacteroides. Antimicrob Agents Chemother 16:565-71.

27. Tzianabos, A. O., Pantosti A., Baumann H., Brisson J. R., Jennings H. J., and Kasper D. L. (1992)The capsular polysaccharide of Bacteroides fragilis comprises two ionically linked polysaccharides. J. Biol. Chem. 267:18230-35.

28. Wexler HM (2007) . Bacteroides: the good, the bad, and the nitty-gritty. Clin Microbiol Rev 20:593-621.

29. Wexler HM. (1991) Susceptibility testing of anaerobic bacteria: myth, magic, or method? Clin Microbiol Rev $4: 470-84$.

30. Yamamoto T, Ugai H, Nakayama-Imaohji H, Tada A, Elahi M, Houchi H, Kuwahara T. (2018) Characterization of a recombinant Bacteroides fragilis sialidase expressed in Escherichia coli. Anaerobe 50:6975. 